\title{
Verifikasi Metode Penentuan Logam Kadmium (Cd) dalam Air Limbah Domestik dengan Metode Spektrofotometri Serapan Atom
}

\author{
Ashadi Sasongko¹, Kurniawan Yulianto², Dwi Sarastri ${ }^{3}$ \\ ${ }^{1}$ Institut Teknologi Kalimantan (ITK), Jl. Soekarno-Hatta km.15 Karangjoang, Balikpapan, 76127 \\ ${ }^{2}$ Balai Besar Teknik Kesehatan Lingkungan dan Pengendalian Penyakit (BBTKLPP), JI. Balai \\ Rakyat No.2, Cakung, Jakarta, 13910 \\ ${ }^{3}$ Program Diploma IPB, JI. Kumbang 14 Bogor, 16151 \\ e-mail: ashadisasongko@itk.ac.id
}

\begin{abstract}
Abstrak
Kadmium (Cd) merupakan logam berat yang memiliki toksisitas yang tinggi. Kadar $\mathrm{Cd}$ perlu diketahui secara pasti karena di lingkungan perairan dapat terakumulasi dan dapat meracuni semua komponen biotik. Penentuan konsentrasi Cd dalam air limbah domestik dapat ditentukan menggunakan spektrofotometer serapan atom (SSA) nyala. Verifikasi metode SSA nyala diperlukan untuk membuktikan bahwa metode yang digunakan dapat dipercaya dan dapat dipertanggungjawabkan secara ilmiah. Parameter verifikasi metode analisis yang diuji yaitu linearitas, akurasi, presisi (keterulangan), limit deteksi, dan limit kuantitasi. Hasil verifikasi metode penentuan Cd dalam air limbah domestik dengan SSA telah memenuhi syarat. Persamaan regresi dari kurva standar yang diperoleh yaitu $\mathrm{y}=$ $0.0011+0.0414 x$ dengan $r$ sebesar 0.9998 , \% recovery berkisar $115.20 \%-119.20 \%$ dengan rerata $116.91 \%$ dan \% RSD yang sebesar $0.69 \%$, lebih kecil dibandingkan dengan $2 / 3$ CV Horwitz yaitu $12.88 \%$. Limit deteksi dan limit kuantitasi berturut-turut sebesar $0.0045 \mathrm{ppm}$ dan $0.0151 \mathrm{ppm}$. Metode penentuan cadmium dalam air limbah domestik dapat diverifikasi dan digunakan untuk analisis sample rutin.
\end{abstract}

Kata kunci : air limbah domestik, kadmium, SSA nyala, verifikasi

\begin{abstract}
Cadmium (Cd) is a heavy metal that has a high toxicity. Concentration of $\mathrm{Cd}$ in water need to be measured exactly because it is bioaccumulative in water and poisons to the biota. Determination of cadmium in domestic wastewater can be determined using flame atomic absorption spectrophotometer (FAAS). Method verification is important to prove that the method can be trusted and can be justified scientifically. Verification parameters of analytical methods tested were linearity, accuracy, precision (repeatability), limit detection, and limit of quantitation. Based on the verification, method of cadmium determination in domestic waste water with AAS are qualified accepted. It was indicated by the regression equation of the standard curve obtained, $y=0.0011+0.0414 x$ with $r=0.9998$. \%recovery obtained was at range $115.20 \%-119.20 \%$ with a mean of $116.91 \%$, \% RSD obtained from the repeatability tent was $0.69 \%$. Repeatability of the results obtained was smaller than $2 / 3$ CV Horwitz, $12.88 \%$. Limit of detection and limit of quantitation respectively obtained by $0.0045 \mathrm{ppm}$ and $0.0151 \mathrm{ppm}$. The method of cadmium determination (Cd) in domestic wastewater are verified and can be used for routine sample analysis.
\end{abstract}

Keywords : domestic wastewater, cadmium, FAAS, verification 


\section{PENDAHULUAN}

Air merupakan kebutuhan pokok bagi kehidupan. Manusia memanfaatkan air untuk berbagai aktivitas dalam kehidupan sehari-hari, salah satunya aktivitas rumah tangga yang banyak memanfaatkan air untuk memasak, mandi, dan mencuci. Pemanfaatan dan pemakaian air tersebut menyebabkan penurunan kualitas air sehingga menghasilkan limbah. Kurang lebih $80 \%$ dari air yang digunakan untuk aktivitas manusia akan dibuang dalam bentuk air limbah.

Air limbah dapat dibagi menjadi 4 golongan antara lain air limbah domestik, air bekas, air hujan, dan air limbah khusus (non-domestik). Menurut Keputusan Menteri Lingkungan Hidup Nomor 112 Tahun 2003, air limbah domestik adalah air limbah yang berasal dari usaha dan atau kegiatan pemukiman, rumah makan, perkantoran, perniagaan, apartemen dan asrama. Berdasarkan karakteristiknya, terdapat dua jenis air limbah domestik yaitu jenis black water yang berasal dari WC dan umumnya ditampung dalam septic tank, sedangkan yang satunya adalah jenis grey water yang berasal dari kegiatan mencuci, mandi, dan memasak yang umumnya langsung dibuang ke saluran drainase maupun perairan umum. Walaupun air limbah jenis grey water sebagian besar merupakan bahan organik yang mudah terdegradasi, namun secara kuantitas cenderung semakin meningkat sejalan dengan pertumbuhan jumlah penduduk.

Air limbah domestik secara umum diperkirakan mengandung 99,9 \% air dan $0,1 \%$ zat padat. Zat padat yang ada terbagi atas lebih kurang $70 \%$ zat organik dan sisanya $30 \%$ zat anorganik terutama pasir, garam-garaman dan logam. Limbah domestik mencakup seluruh limbah rumah tangga yang dibuang ke dalam saluran pembuangan, termasuk limbah sebagian industri kecil yang sulit diidentifikasi dan dihitung secara terpisah. Air limbah domestik yang tidak diolah terlebih dahulu dan langsung dibuang ke sungai, danau, dan laut akan mengakibatkan pencemaran. Aktivitas masyarakat, seperti pembuangan limbah pasar dan limbah rumah tangga, serta aktivitas perbaikan dan pengecatan kapal di perairan yang kemudian terbawa oleh air dan angin menjadi sumber tersebarnya logam berat ke lingkungan perairan (Rumahlatu, 2011).

Logam berat adalah unsur-unsur kimia dengan bobot jenis lebih besar dari $5 \mathrm{gr} / \mathrm{cm}^{3}$ dan memiliki nomor atom antara 22 sampai 92. Terdapat 80 dari 109 unsur kimia di muka bumi ini yang telah teridentifikasi sebagai jenis logam berat. Beberapa logam berat yang berbahaya dan sering mencemari lingkungan adalah merkuri $(\mathrm{Hg})$, timbal $(\mathrm{Pb})$, arsen $(\mathrm{As})$, kadmium (Cd), krom $(\mathrm{Cr})$, dan nikel (Ni). Adanya logam berat di perairan, sangat berbahaya terhadap kehidupan organisme, maupun efeknya secara tidak langsung terhadap kesehatan manusia.

Banyak logam berat yang tersebar ke lingkungan dan berpotensi masuk ke dalam rantai makanan. Beberapa logam berat (misalnya, $\mathrm{Hg}, \mathrm{Pb}, \mathrm{Cd}$ ) sangat beracun bagi manusia. Penentuan konsentrasi logam berat menjadi penting untuk menjaga kesehatan manusia (Imyim dkk., 2013). Bahkan Dewa dan Hadinoto (2015) menyatakan pentingkan analisis untuk memastikan produk air minum dalam kemasan (AMDK) terbebas dari bahan pencemar,seperti $\mathrm{Pb}$ dan $\mathrm{Cd}$ meskipun dalam pengolahannya menggunakan sistem dan peralatan yang sangat canggih (Dewa dan Hadinoto, 2015). Di China, analisis kandungan logam berat seperti kadmium dan kromium, dilakukan terhadap 25 sampel produk teh seperti teh hijau, kuning, putih, oolong, hitam, dan teh melati, menggunakan spektrometer serapan atom (SSA) tungku grafit. (Zhong dkk., 2015). Junior dkk. (2014) juga telah meneliti kandungan $\mathrm{Cd}$ dalam produk cuka menggunakan SSA elektrotermal.

Chwastowska dkk. (2008) telah mengembangkan metode untuk meningkatkan sensitivitas dalam analisis $\mathrm{Cd}$ $\mathrm{Pb}$ dan $\mathrm{Cu}$ pada produk-produk makanan dan material lingkungan menggunakan SSA tungku grafit. Zmozinski dkk. (2013) juga mengembangkan metode penentuan konsentrasi $\mathrm{Cd}$ dan $\mathrm{Pb}$ pada sampel ikan menggunakan SSA elektrotermal. Prosedur ini sangat sesuai untuk aplikasi rutin. Penelitian tersebut menunjukkan bahwa 
analisis langsung ikan segar dengan SSA elektrotermal dapat diterapkan sebagai prosedur skrining cepat, yang memberikan informasi untuk pengendalian kontaminasi yang efektif.

Cd merupakan logam berat yang memiliki toksisitas yang tinggi setelah $\mathrm{Hg}$. Level maksimum Cd dalam air limbah yang diperbolehkan berdasarkan Keputusan Menteri Negara Lingkungan Hidup Nomor : KEP-51/MENLH/10/1995 tentang Baku Mutu Limbah Cair Bagi Kegiatan Industri adalah sebesar $0.05 \mathrm{ppm}$. Cd termasuk ke dalam logam berat tidak esensial, yakni logam yang keberadaannya dalam tubuh masih belum diketahui manfaatnya bahkan bersifat toksik, sehingga adanya logam $\mathrm{Cd}$ perlu diketahui secara pasti dalam perairan sebab kadar yang terlalu tinggi dapat berdampak buruk bagi kesehatan.

Cd sering digunakan sebagai bahan utama atau tambahan materi dalam industri, antara lain industri elektroplating, baterai nikel-kadmium, bahan coating, bahan stabilizers dalam industri plastik dan barang sintetis lain. Cd membahayakan kesehatan melalui rantai makanan. Hewan dengan mudah menyerap $\mathrm{Cd}$ dari makanan dan terakumulasi dalam jaringan seperti ginjal, hati, dan alat-alat reproduksi (Withgott dan Brennan, 2007). Cd bersifat bioakumulatif, biomagnifikasi, toksik, dan karsinogenik, sehingga logam berat di lingkungan dapat terakumulasi pada jaringan tubuh makhluk hidup yang berada di lingkungan tersebut, sehingga apabila mencapai konsentrasi toksik dapat meracuni semua komponen biotik (hewan, tumbuhan, maupun manusia. Toksisitas Cd bisa merusak sistem fisiologis, sistem respirasi, sistem sirkulasi darah dan jantung, kerusakan sistem reproduksi, sistem syaraf bahkan dapat mengakibatkan kerapuhan tulang, kerusakan ginjal dan menurunkan fungsi pulmo dalam tubuh (Widowati et al 2008).

Di Indonesia, analisis logam berat banyak dilakukan dengan menggunakan SSA nyala. SSA nyala lebih popular daripada jenis SSA lain karena memiliki banyak keunggulan diantaranya adalah cara operasional dan preparasi sampel sederhana, sensitivitas tinggi, selektif, dan interferensi spektrum rendah (Correia dan
Oliveira, 2004). Penentuan Cd dalam air limbah domestik menggunakan SSA nyala didasarkan pada proses penyerapan energi radiasi oleh atom-atom yang berada pada tingkat energi dasar. Dengan mengukur intensitas radiasi yang diteruskan atau mengukur intensitas radiasi yang diserap, maka konsentrasi unsur dalam sampel dapat ditentukan.

Penentuan Cd pada air limbah domestik menggunakan SSA nyala telah dilakukan di berbagai laboratorium. Namun guna mengkonfirmasi metode yang telah digunakan untuk analisis rutin dalam laboratorium, maka perlu dilakukan verifikasi metode secara berkala.

Verifikasi metode bertujuan untuk memastikan bahwa analis dapat menerapkan metode analisis dengan baik dan menjamin mutu hasil pengujian. Verifikasi perlu dilakukan oleh suatu laboratorium analisis apabila terjadi pergantian instrumen yang digunakan untuk analisis rutin. Instrumen dengan spesifikasi berbeda akan memiliki hasil analisis yang berbeda pula. Metode yang telah digunakan dalam waktu yang cukup lama juga perlu dilakukan verifikasi. Parameter uji untuk verifikasi metode hampir sama dengan parameter uji validasi. Namun, pada percobaan hanya sebagian parameter yang digunakan dalam verifikasi yaitu linearitas, akurasi, presisi, limit deteksi, dan limit kuantitasi (Harmita 2004).

\section{METODE \\ Alat dan Bahan}

Alat-alat yang digunakan adalah konduktometer, $\mathrm{pH}$ meter, penangas air, labu Erlenmeyer $250 \mathrm{~mL}$, pipet Mohr $10 \mathrm{~mL}$ dan $1 \mathrm{~mL}$, bulb, gelas ukur $100 \mathrm{~mL}$, gelas piala $100 \mathrm{~mL}$, labu takar $50 \mathrm{~mL}$, labu takar $100 \mathrm{~mL}$, pipet tetes, corong, botol sampel, lemari asam, instrumen FAAS Hitachi tipe Z2000, konduktometer, dan $\mathrm{pH}$ meter. Bahan-bahan yang digunakan adalah sampel air limbah domestik, akuades, $\mathrm{HNO}_{3}$ $65 \%$, larutan standar multielement 100 ppm, kertas saring, dan akuabides.

\section{Pengujian kualitas air limbah domestik}

Sebelum sampel air limbah domestik diukur menggunakan SSA nyala (FAAS), 
kualitas air limbah domestik diuji terlebih dahulu, dengan cara menguji sifat fisika yaitu warna, bau, suhu, daya hantar listrik (DHL), dan $\mathrm{pH}$.

Sifat fisika sampel air limbah domestik yang digunakan dalam kegiatan ini, tertera pada Tabel 1. Seluruh parameter dari sifat fisika air limbah domestik telah memenuhi syarat batas maksimum yang diizinkan sesuai KEP/MNLH/112/2003. Hal ini ditunjukkan dengan air limbah domestik yang tidak berbau, memiliki warna kuning kecoklatan dengan suhu $24.2^{\circ} \mathrm{C}$, DHL sebesar $1169 \mu \mathrm{S} / \mathrm{cm}$, dan $\mathrm{pH}$ sebesar 7.35.

Tabel 1. Hasil pengujian sifat fisika sampel air limbah domestik

\begin{tabular}{|c|c|c|c|}
\hline Parameter & Satuan & $\begin{array}{c}\text { Batas kadar } \\
\text { maks. }\end{array}$ & $\begin{array}{c}\text { Hasil } \\
\text { analisis }\end{array}$ \\
\hline Bau & - & Tidak berbau & $\begin{array}{l}\text { Tidak } \\
\text { berbau }\end{array}$ \\
\hline Warna & - & - & $\begin{array}{l}\text { Kuning } \\
\text { kecoklatan }\end{array}$ \\
\hline Suhu & ${ }^{\circ} \mathrm{C}$ & Suhu udara $\pm 3^{\circ} \mathrm{C}$ & 24.2 \\
\hline $\mathrm{DHL}$ & $\mu \mathrm{S} / \mathrm{cm}$ & $20-1500$ & 1169 \\
\hline $\mathrm{pH}$ & - & $6-9$ & 7.35 \\
\hline
\end{tabular}

\section{Pembuatan larutan deret standar}

Pembuatan larutan deret standar dibuat dari larutan stok standar multielement konsentrasi $100 \mathrm{ppm}$. Deret standar dibuat dengan konsentrasi cadmium masingmasing $0.05 ; 0.1 ; 0.3 ; 0.5$; dan 1 ppm. Larutan stok yang dipipet masing-masing sebanyak $0.05,0.1,0.3,0.5$, dan $1 \mathrm{~mL}$ ke dalam labu takar $100 \mathrm{~mL}$, kemudian tiaptiap labu takar ditepatkan volumenya hingga $100 \mathrm{~mL}$ dengan akuabides.

Tabel 2. Kondisi instrumen SSA nyala

\begin{tabular}{lc}
\hline \multicolumn{1}{c}{ Parameter } & Keterangan \\
\hline $\begin{array}{l}\text { Panjang gelombang } \\
(\mathrm{nm})\end{array}$ & 228.8 \\
$\begin{array}{l}\text { Tipe nyala } \\
\text { Kecepatan aliran gas }\end{array}$ & Udara-asetilen \\
$\begin{array}{l}\text { pembakar (L/min) } \\
\text { Kecepatan aliran }\end{array}$ & 1.8 \\
$\begin{array}{l}\text { udara (L/min) } \\
\text { Ketinggian tungku } \\
\text { (mm) }\end{array}$ & 15.0 \\
Waktu pengukuran (s) & 5.0 \\
\hline
\end{tabular}

Larutan diukur menggunakan instrumen SSA dengan kondisi alat yang dapat dilihat pada Tabel 2 (Saracoglu dkk., 2002) (Ciobanu dkk., 2013).

\section{Preparasi sampel}

Preparasi sampel yang dilakukan pada percobaan mengacu pada SNI 066989.16-2004 tentang Cara Uji Kadmiun dalam Air dan Air Limbah dengan Metode Spektrofotometer Serapan Atom (SSA) Nyala (BSN, 2004). Sampel air limbah domestik sebanyak $50 \mathrm{~mL}$ dimasukkan kedalam erlenmeyer $250 \mathrm{~mL}$, lalu ditambahkan $\mathrm{HNO}_{3} 65 \%$ sebanyak $5 \mathrm{~mL}$. Sampel didestruksi diatas penangas air pada suhu $120^{\circ} \mathrm{C}$ sampai volume sampel $\pm 15 \mathrm{~mL}$, lalu sampel didinginkan. Setelah sampel dingin, sampel disaring dan ditambahkan dengan akuades sampai tanda tera, lalu ditempatkan kedalam labu takar 50 $\mathrm{mL}$.

\section{Uji Linearitas}

Penentuan linearitas dilakukan dengan larutan deret standar yang telah dibuat dengan konsentrasi $0.05 ; 0.1 ; 0.3$; 0.5; dan $1 \mathrm{ppm}$ diukur menggunakan SSA pada panjang gelombang $228.8 \mathrm{~nm}$ sehingga diperoleh kurva standar (absorbansi terhadap konsentrasi) dan persamaan regresi yang dinyatakan dengan $y=a+b x$. Uji linearitas dikatakan baik jika nilai koefisien korelasi ( $r$ ) yang diperoleh mendekati 1.

\section{Uji Akurasi}

Uji akurasi dilakukan dengan metode penambahan standar. Ke dalam sampel ditambahkan larutan standar multielement 0.05 ppm dari larutan induk 1 ppm sebanyak $2.5 \mathrm{~mL}$, kemudian ditepatkan dengan akuades dalam labu takar $50 \mathrm{~mL}$. Pengukuran dilakukan sebanyak 7 kali ulangan. Sampel uji diukur dengan SSA pada panjang gelombang $228.8 \mathrm{~nm}$. Sehingga diperoleh \% recovery dari masingmasing pengukuran dengan rumus sebagai berikut:

$$
\% \text { recovery }=\frac{\mathrm{a}-\mathrm{b}}{\mathrm{c}} \times 100 \%
$$


Keterangan :

$\mathrm{a}=$ konsentrasi sampel+standar yang terukur (ppm)

$\mathrm{b}=$ konsentrasi sampel (ppm)

$\mathrm{c}=$ konsentrasi standar teoritis yang ditambahkan (ppm)

\section{Uji Presisi}

Uji presisi (keterulangan) dilakukan dengan pengukuran larutan standar multielement 0.3 ppm. Pengukuran dilakukan sebanyak 10 kali ulangan. Sehingga diperoleh Relative Standard Deviation (\% RSD) dari beberapa ulangan dan dari nilai simpangan baku tersebut dapat dihitung nilai 2/3 CV Horwitz. Nilai \% RSD uji keterulangan hasil pengujian harus lebih kecil dari $2 / 3 \mathrm{CV}$ Horwitz yang ditentukan dengan rumus sebagai berikut :

$$
\begin{gathered}
\% \mathrm{RSD}=\frac{S D}{\bar{x}} \times 100 \% \\
\frac{2}{3} \mathrm{CV} \text { Horwitz }=\frac{2}{3} 2^{1-0.5 \log \mathrm{C} \times 100 \%}
\end{gathered}
$$

Keterangan :

$$
\begin{array}{ll}
\mathrm{SD} & =\text { Standar deviasi } \\
\bar{x} & =\text { Rerata konsentrasi terukur }(\mathrm{ppm}) \\
\mathrm{C} & =\text { Rerata konsentrasi terukur }(\mathrm{ppm})
\end{array}
$$

\section{Limit deteksi (LD) \& Limit kuantitasi (LK)}

Penentuan LD dan LK dilakukan dengan mengukur deret standar sebanyak 7 serial standar yang diukur sebanyak 7 kali ulangan. Dari 7 serial standar tersebut, didapatkan intersep dan slope pada masingmasing persamaan garis. Nilai LD dan LK dapat ditentukan dengan rumus sebagai berikut:

$$
Q=\frac{k \times S D}{S I}
$$

Keterangan :

$\mathrm{Q} \quad=$ Limit deteksi atau limit kuantitasi

SD = Standar deviasi

$\mathrm{SI}=$ Kemiringan kurva linear (slope)

$\mathrm{k}=$ Tetapan (3 untuk LD dan 10 untuk LK)

\section{HASIL DAN PEMBAHASAN}

Pencemaran lingkungan perairan dapat disebabkan oleh komponen organik (limbah cair) maupun komponen anorganik (logam berat). Sebagian logam berat seperti Cd merupakan zat pencemar yang berbahaya. Afinitas yang tinggi terhadap unsur $S$ menyebabkan logam tersebut menyerang ikatan belerang dalam enzim, sehingga enzim yang bersangkutan menjadi tidak aktif. Gugus karboksilat $(-\mathrm{COOH})$ dan amina $\left(-\mathrm{NH}_{2}\right)$ juga bereaksi dengan logam berat. Cd terikat pada sel-sel membran yang menghambat proses transpormasi melalui dinding sel. Logam berat biasanya ditemukan sangat sedikit sekali dalam air secara alamiah yaitu kurang dari $1 \mu \mathrm{g} / \mathrm{L}$. Untuk menentukan kualitas air berdasar konsentrasi logam dalam air agak sulit karena erat hubungannya dengan partikel tersuspensi yang terlarut didalamnya.

Kualitas air yaitu sifat air dan kandungan makhluk hidup, zat energi atau komponen lain di dalam air (Effendi 2003). Kualitas air dinyatakan dengan beberapa parameter yaitu parameter fisika, parameter kimia, dan parameter biologi.. Kualitas air limbah dapat diketahui dari karakteristik fisika yang ditentukan berdasarkan beberapa parameter yaitu bau, suhu, warna, $\mathrm{DHL}$, dan $\mathrm{pH}$. Sifat fisika dapat dikenali secara visual, namun untuk mengetahui secara lebih pasti maka digunakan analisis laboratorium (Ginting 2002).

Sampel air limbah yang telah diuji sifat fisikanya, dapat digunakan untuk verifikasi metode penentuan logam kadmium (Cd) dalam air limbah domestik menggunakan SSA. Sebelum diukur menggunakan SSA, sampel dipreparasi terlebih dahulu dengan cara menambahkan pereaksi asam tertentu ke dalam suatu bahan yang dianalisis. Asam-asam yang dapat digunakan adalah asam-asam pengoksidasi seperti $\mathrm{H}_{2} \mathrm{SO}_{4}$, $\mathrm{HNO}_{3}, \mathrm{H}_{2} \mathrm{O}_{2}, \mathrm{HClO}_{4}$, atau campurannya. Kandungan matriks atau ion-ion lain dapat mengganggu proses analisis logam berat dengan SSA, maka dilakukan destruksi dengan memutuskan ikatan unsur logam dengan komponen lain dalam matriks sehingga unsur tersebut berada dalam keadaan bebas. Proses destruksi pada percobaan dilakukan dengan 
menambahkan asam kuat yaitu $\mathrm{HNO}_{3} 65 \%$ kedalam sampel yang berfungsi untuk merombak bentuk logam organik menjadi logam-logam anorganik sehingga menjadi bentuk ion bebas yang dapat dianalisis menggunakan SSA pada panjang gelombang $228.8 \mathrm{~nm}$. Pemilihan instrumen SSA dikarenakan pengerjaannya cepat, sensitif, spesifik untuk unsur yang ditentukan, dan dapat digunakan untuk penentuan kadar unsur yang konsentrasinya sangat kecil tanpa harus dipisahkan terlebih dahulu.

\section{Verifikasi Metode}

Verifikasi metode merupakan pengujian terhadap metode standar (metode baku) atau metode yang telah divalidasi pada saat mulai digunakan sampai pada waktu tertentu secara berkala. Sementara validasi metode adalah konfirmasi pengujian dan pengadaan bukti yang objektif bahwa persyaratan tertentu untuk suatu maksud khusus telah dipenuhi. Kedua metode tersebut dilakukan sebelum menggunakan metode baru yang digunakan sebagai metode untuk analisis rutin. Verifikasi metode penentuan $\mathrm{Cd}$ dalam air limbah domestik dilakukan menggunakan beberapa parameter yaitu linearitas, akurasi, presisi, limit deteksi, dan limit kuantitasi.

\section{Linearitas}

Linearitas merupakan metode analisis uji untuk memastikan adanya hubungan yang linearitas antara konsentrasi analit dan sinyal atau respon detektor. Penentuan linearitas memerlukan sedikitnya lima konsentrasi standar yang berbeda-beda. Pengukuran linearitas ditunjukkan dari hasil grafik, yang menghasilkan suatu persamaan garis linear yang menghubungkan antara sinyal dengan konsentrasi suatu standar yang menunjukkan koefisien korelasi $(r)$.

Uji linearitas dilakukan dengan cara membuat deret standar dengan lima titik konsentrasi yaitu $0.05 ; 0.1 ; 0.3 ; 0.5$; dan 1 ppm. Hasil pengukuran deret standar menggunakan SSA dapat dilihat pada Tabel 3.

Berdasarkan hasil uji linearitas pada Tabel 3, diperoleh persamaan garis dari kurva standar $\mathrm{y}=0.0011+0.0414 \mathrm{x}$ dengan koefisien korelasi $(r)$ sebesar 0.9998. Nilai tersebut telah memenuhi persyaratan yang telah ditentukan yaitu kurva dikatakan baik jika nilai koefisien korelasi > 0.995 (AOAC 2003).

Tabel 2. Hasil uji linearitas

\begin{tabular}{lcc}
\hline $\begin{array}{c}\text { Konsentrasi standar } \\
(\mathrm{ppm})\end{array}$ & Absorbansi \\
\hline 0.05 & 0.0033 \\
& 0.10 & 0.0049 \\
& 0.30 & 0.0138 \\
& 0.50 & 0.0216 \\
& 1.00 & 0.0425 \\
\hline Slope & & 0.0414 \\
Intersep & & 0.0011 \\
Koefisien korelasi $(r)$ & 0.9998 \\
\hline
\end{tabular}

Hal ini dapat dikatakan bahwa kisaran konsentrasi 0.05 sampai dengan $1 \mathrm{ppm}$ menghasilkan hubungan linear yang baik antara konsentrasi dengan absorbansi yang terbaca. Kurva standar dapat dilihat pada Gambar 1.

Berdasarkan Gambar 1, setiap titik mendekati garis lurus yang terbentuk sehingga dapat dikatakan kurva standar yang dibuat telah linear. Kurva tidak harus melewati titik (0.0), karena pada beberapa kasus penambahan titik (0.0) sebagai kurva standar akan membuat garis tidak linear.

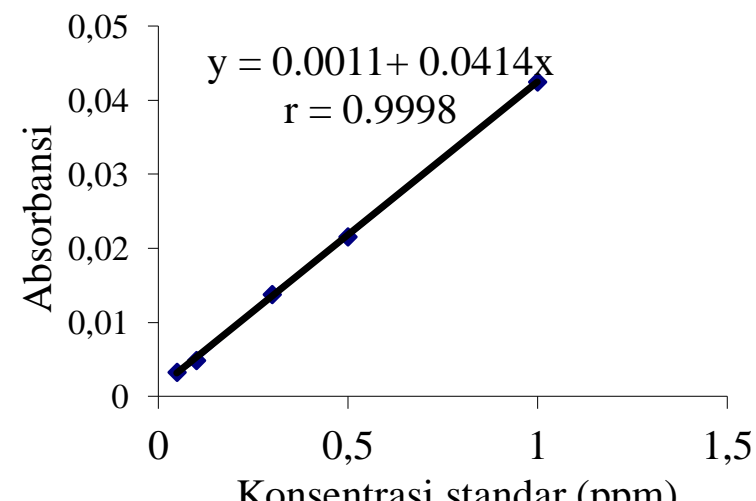

Gambar 1. Kurva hubungan antara konsentrasi standar terhadap absorbansi

Jurnal Sains dan Teknologi| 233 
Nilai intersepsi menunjukkan rerata absorbansi (y) ketika konsentrasi (x) nol. Nilai intersepsi dapat dibuat nol dari pengolahan data SSA, namun hal tersebut tidak dilakukan. Karena nilai intersepsi harus selalu muncul pada setiap pengukuran yang membutuhkan ketelitian. Hasil intersepsi yang ideal yaitu lebih kecil dari nilai slope. Intersepsi boleh lebih besar dari slope asalkan nilai intersepsi tidak lebih besar dari batas deteksi. Nilai intersepsi dan slope yang diperoleh berdasarkan uji linearitas berturut-turut yaitu 0.011 dan 0.0414 . Hasil tersebut menandakan bahwa nilai intersepsi telah memenuhi syarat.

\section{Akurasi}

Akurasi merupakan ukuran yang menunjukkan derajat kedekatan hasil analisis dengan kadar analit yang sebenarnya. Akurasi dinyatakan sebagai persen perolehan kembali (\% recovery) analit yang ditambahkan. Akurasi dapat ditentukan dengan metode penambahan baku standar atau biasa disebut metode adisi standar. Metode adisi standar dengan menambahkan sejumlah analit standar sesuai dengan konsentrasi tertentu ke dalam suatu sampel yang akan dianalisis (Harmita 2004). Uji akurasi dilakukan dengan metode penambahan standar atau biasa disebut dengan spike yaitu menambahkan larutan standar multielement dengan konsentrasi $0.05 \mathrm{ppm}$ ke dalam sampel yang telah diketahui konsentrasinya.

Tabel 3. Hasil uji akurasi

\begin{tabular}{rcc}
\hline Ulangan & $\begin{array}{c}\text { Konsentrasi } \\
\text { terukur (ppm) }\end{array}$ & \% recovery \\
\hline 1 & 0.047 & 119.20 \\
2 & 0.046 & 117.20 \\
3 & 0.045 & 115.20 \\
4 & 0.045 & 115.20 \\
5 & 0.046 & 117.20 \\
6 & 0.045 & 115.20 \\
7 & 0.047 & 119.20 \\
\hline Rerata & \multicolumn{2}{c}{116.91} \\
SD & \multicolumn{2}{c}{1.79} \\
\% RSD & \multicolumn{2}{c}{1.53} \\
\hline
\end{tabular}

Sampel yang telah dispike dianalisis sehingga didapatkan nilai \% recovery. Hasil uji akurasi dapat dilihat pada Tabel 4.

Berdasarkan Tabel 4, dapat dilihat bahwa \% recovery yang diperoleh berada dalam rentang 115.20 - $119.20 \%$ dengan rerata $116.91 \%$. Hasil penentuan \% recovery dari hasil akurasi menunjukkan nilai yang cukup baik. Hal tersebut dikarenakan nilai \% recovery yang diperoleh telah memenuhi syarat keberterimaan yang ditetapkan oleh AOAC (2003) yaitu 75-120 $\%$. Nilai \% recovery seluruh hasil pengujian menunjukkan kecenderungan berada diatas $100 \%$. Nilai \% recovery yang ideal yaitu $100 \%$, apabila nilai tersebut kurang atau lebih maka terjadi kesalahan saat pengukuran sampel. Kesalahan yang terjadi dapat bersifat acak. Kesalahan acak tidak dapat dihilangkan tetapi dapat diminimalkan dengan melakukan penentuan berulang. Kesalahan ini timbul karena ada perubahan terhadap kesalahan sistematik.

\section{Presisi}

Presisi merupakan kedekatan antara hasil pengujian individu dalam serangkaian pengukuran terhadap suatu sampel yang homogen. Presisi biasanya dinyatakan sebagai simpangan baku relatif atau relative standard deviation (RSD). Presisi memiliki 3 level yaitu keterulangan (repeatibility), presisi intermediet, ketertiruan (reproducibility). Keterulangan merupakan pengukuran yang dihasilkan pada kondisi pengoperasian yang sama dan waktu yang pendek. Presisi intermediet merupakan pengukuran yang ditunjukkan dalam berbagai variasi laboratorium atau variasi hari, analis, dan peralatan yang digunakan. Ketertiruan merupakan suatu kemampuan meniru data dalam presisi yang telah ditetapkan, serta lebih banyak variasi dengan menggunakan metode yang sama (Harmita 2004).

Uji presisi yang dilakukan pada percobaan adalah uji terhadap keterulangan. Uji keterulangan dapat digunakan untuk mengetahui adanya galat acak yang berasal dari preparasi sampel, seperti pemanasan sampel, pembuatan larutan, penyaringan, dan kondisi instrumen SSA yang digunakan. Uji keterulangan 
dilakukan pada hari yang sama dengan pengukuran standar $0.3 \mathrm{ppm}$ sebanyak sepuluh kali ulangan. Presisi dinyatakan dalam \% RSD.

Tabel 5. Hasil uji presisi (keterulangan)

\begin{tabular}{|c|c|c|}
\hline Ulangan & $\begin{array}{l}\text { Konsentrasi } \\
\text { terukur (ppm) }\end{array}$ & Absorbansi \\
\hline 1 & 0.285 & 0.0125 \\
\hline 2 & 0.289 & 0.0130 \\
\hline 3 & 0.287 & 0.0126 \\
\hline 4 & 0.283 & 0.0123 \\
\hline 5 & 0.287 & 0.0126 \\
\hline 6 & 0.285 & 0.0124 \\
\hline 7 & 0.286 & 0.0125 \\
\hline 8 & 0.285 & 0.0124 \\
\hline 9 & 0.285 & 0.0124 \\
\hline 10 & 0.285 & 0.0125 \\
\hline Rerata & 0.286 & 0.0125 \\
\hline $\begin{array}{l}\text { Standar } \\
\text { deviasi }\end{array}$ & \multicolumn{2}{|c|}{0.002} \\
\hline$\%$ RSD & \multicolumn{2}{|c|}{$0.69 \%$} \\
\hline $\begin{array}{l}\text { 2/3 CV } \\
\text { Horwitz }\end{array}$ & \multicolumn{2}{|c|}{$12.88 \%$} \\
\hline
\end{tabular}

Hasil uji keterulangan menghasilkan rerata konsentrasi standar sebesar 0.286 ppm, dengan standar deviasi sebesar 0.002 , dan \% RSD sebesar $0.69 \%$. Hasil uji keterulangan dapat dilihat pada Tabel 5.

Menurut AOAC (2003) nilai \% RSD <1 dapat dikatakan sangat teliti, sehingga hasil uji keterulangan yang dilakukan dapat dikatakan sangat teliti. Syarat keberterimaan digunakan koefisien variasi Horwitz sesuai dengan AOAC. Nilai \% RSD yang diperoleh untuk uji keterulangan harus lebih kecil dari 2/3 CV Horwitz (Novelina et al 2009). Berdasarkan Tabel 6, hasil perhitungan \% RSD yang diperoleh lebih kecil dibandingkan nilai 2/3 CV Horwitz. Hal ini membuktikan bahwa ketelitian analisis yang dilakukan baik karena telah memenuhi syarat keberterimaan.

\section{Limit Deteksi (LD) dan Limit Kuantitasi (LK) \\ Limit deteksi merupakan jumlah} terkecil analit dalam sampel yang masih dapat dideteksi. Limit kuantitasi merupakan jumlah terkecil analit dalam sampel yang masih dapat dikuantitasi secara tepat. Berdasarkan pengertian tersebut, sebenarnya tidak ada perbedaan yang signifikan antara limit deteksi dan limit kuantitasi, sehingga prosedur analisis yang dilakukan cukup satu metode, namun kedua metode dibedakan berdasarkan cara perhitungannya (Harmita 2004).

Penentuan LD dan LK dilakukan dengan pengukuran deret standar sebanyak 7 serial standar yang diukur sebanyak 7 kali ulangan. Data yang dibutuhkan yaitu nilai absorbansi dan slope persamaan garis yang digunakan. Hasil penentuan LD dan LK dapat dilihat pada Tabel 6 .

Tabel 6. Hasil pengukuran untuk LD dan LK

\begin{tabular}{lc}
\multicolumn{1}{c}{ Parameter } & $\begin{array}{c}\text { Hasil percobaan } \\
\text { (ppm) }\end{array}$ \\
\hline Limit Deteksi (LD) & 0.0045 \\
Limit Kuantitasi (LK) & 0.0151 \\
\hline
\end{tabular}

Berdasarkan Tabel 6, hasil pengukuran limit deteksi metode untuk penentuan logam kadmium menunjukkan konsentrasi terkecil yang masih dapat terukur sebesar $0.0045 \mathrm{ppm}$. Berdasarkan hasil tersebut, dapat diketahui bahwa kadar kadmium dalam limbah domestik > 0.0045 ppm dapat terbaca sebagai sinyal analit oleh SSA tipe Hitachi Z-2000, tetapi apabila konsentrasi analit $<0.0045$ ppm sinyal yang dihasilkan tidak dapat dipercaya sebagai analit melainkan noise. Jumlah terkecil analit yang masih dapat dikuantitasi sebesar $0.0151 \mathrm{ppm}$. Hal ini menunjukkan bahwa kadar kadmium dalam limbah domestik yang lebih besar dari $0.0151 \mathrm{ppm}$ dapat dikuantitasi dengan baik, sedangkan apabila kadar analit lebih kecil dari 0.0151 ppm tidak dapat dikuantitasi dengan baik. Nilai LD dan LK didapatkan dengan cara mengalikan standar deviasi dengan $\mathrm{k}$ (tetapan) yaitu 3 untuk LD dan 10 untuk LK, lalu dibagi dengan slope pada persamaan regresi linear. 


\section{SIMPULAN}

Berdasarkan semua parameter yang diujikan yaitu linearitas, akurasi, presisi, limit deteksi, dan limit kuantitasi, metode penentuan logam kadmium (Cd) dalam air limbah domestik menggunakan SSA telah memenuhi syarat keberterimaan dan dapat digunakan untuk metode analisis rutin. Hal ini ditunjukkan dengan linearitas yang baik dengan persamaan garis dari kurva standar $y=0.0011+0.0414 x$ dengan $r=0.9998$. \% recovery yang didapatkan sebesar $116.91 \%$, \% RSD sebesar $0.69 \%$, limit deteksi dan limit kuantitasi berturut-turut diperoleh sebesar 0.0045 ppm dan 0.0151 ppm.

\section{UCAPAN TERIMA KASIH}

Terima kasih kepada Balai Besar Teknik Kesehatan Lingkungan dan Pengendalian Penyakit (BBTKLPP), Jl. Balai Rakyat No.2, Cakung, Jakarta, 13910 yang telah memberikan fasilitas berupa instrumen dan bahan kimia dalam kegiatan ini.

\section{DAFTAR PUSTAKA}

AOAC. (2003). Guidelines for Single Laboratory Validation of Chemical Methods for Dietary Supplements and Botanicals. AOAC Official. Diunduh dari:

http://www.aoac.org/aoac_prod_imis/A OAC_Docs/StandardsDevelopment/SL V_Guidelines_Dietary_Supplements.p df

BSN. (2004). SNI 06-6989.16-2004: Cara Uji Kadmium dalam Air dan Air Limbah dengan Metode Spektrofotometer Serapan Atom (SSA) Nyala. Badan Standardisasi Nasional (BSN)

Chwastowska, J., Skwara, W., Sterliñska, E., \& Dudek, J. (2008). GF AAS Determination of Cadmium, Lead and Copper in Environmental Materials and Food Products after Separation on Dithizone Sorbent, Chem. Anal. (Warsaw), 53, 887-894

Ciobanu, C., Șlencu, B. G., \& Cuciureanu, R. (2013). FAAS Determination of Cadmium and Lead Content in
Foodstuffs from North-Eastern Romanian Market, Studia Universitatis "Vasile Goldiş" Seria Ştiinţele Vieţii, 23 (1), 33-38.

Correia, P. R. M. \& Oliveira, P. V, (2004). Simultaneous Atomic Absorption Spectrometry for Cadmium and Lead Determination in Wastewater, Journal of Chemical Education, 81(8), 11741176

Dewa, R. P. \& Hadinoto, S., (2015). Analisa Kandungan Timbal $(\mathrm{Pb})$ dan Kadmium (Cd) Pada Air Minum Dalam Kemasan Di Kota Ambon, Majalah BIAM, 11(2), 76-82

Harmita, (2004). Petunjuk Pelaksanaan Validasi Metode dan Cara Perhitungannya, Majalah IImu Kefarmasian, 1(3), 117-135

Imyim, A., Daorattanachai, P., \& Unob, F. (2013). Determination of Cadmium, Nickel, Lead, and Zinc in Fish Tissue by Flame and Graphite Furnace Atomic Absorption after Extraction with Pyrrolidine Dithiocarbamate and Activated Carbon, Analytical Letters, 46, 2101-2110

Junior, M. M. S., Silva, L. O. B., Leão, D. J., \& Ferreira, S. L. C. (2014). Analytical strategies for determination of cadmium in Brazilian vinegar samples using ET AAS. Food Chemistry, 160, 209-213

Rumahlatu, D. (2011). Konsentrasi Logam Berat Kadmium Pada Air, Sedimen dan Deadema setosum (Echinodermata, Echinoidea) di Perairan Pulau Ambon, IImu Kelautan, 16(2), 78-85

Saracoglu, S., Divrikli, U., Soylak, M., \& Elci, L. (2002). Determination of Copper, Iron, Lead, Cadmium, Cobalt and Nickel by Atomic Absorption Spectrometry in Baking Powder and Baking Soda Samples after Preconcentration and Separation, Journal of Food and Drug Analysis, 10(3), 188-194

Widowati, W., Sastiono, A., \& Jusuf, R., (2008). Efek Toksik Logam Pencegahan dan Penanggulangan Pencemaran. Jakarta : Andi

Withgott, J. \& Brennan S., (2007). 
Environment: The Science Behind the Stories. San Fransisco: Pearson Benjamin Cummings

Zhong, W., Ren, T., \& Zhao, L. (2015). Determination of $\mathrm{Pb}$ (Lead), $\mathrm{Cd}$ (Cadmium), $\mathrm{Cr}$ (Chromium), $\mathrm{Cu}$ (Copper), and $\mathrm{Ni}$ (Nickel) in Chinese tea with high-resolution continuum source graphite furnace atomic absorption spectrometry. Journal of Food and Drug Analysis, XXX, 1-10

Zmozinski, A. V, Passos, L. D., Damin, I. C. F., Esp, M. A. B., \& Vale, G. R. (2013). Analytical Methods Determination of cadmium and lead in fresh $\mathrm{fi}$ sh samples by direct sampling electrothermal atomic absorption spectrometry, Anal. Methods, 5, 64166424 